\title{
ARCHITEKCI POWIATOWI \\ W POWIECIE BIALSKIM (1918-1939). \\ PRZYCZYNEK DO BADAŃ NAD DZIEJAMI ARCHITEKTURY WOJEWÓDZTWA LUBELSKIEGO
}

Artykuł dotyczy architektów i budowniczych powiatowych urzędujących w powiecie bialskim w okresie międzywojennym ${ }^{1}$. Tereny tego powiatu, zajmującego północno-wschodni obszar województwa lubelskiego, mocno ucierpiały podczas działań pierwszej wojny światowej. W gminach Dobryń, Piszczac, Kobylany, Kostomłoty, Zabłocie, Tuczna, Sikorki i Dubów, a także takich miejscowościach jak Kodeń, Terespol i Łomazy straty w zabudowie szacowano na 80\% („Starostwo Bialskie” 2). Powojenną odbudowę wspierano długoterminowymi, a nawet bezzwrotnymi pożyczkami, udzielanymi najpierw przez Powiatowe Biuro Odbudowy, a po likwidacji tego urzędu w 1924 r. przez starostwa powiatowe. Mimo to dopiero w 1929 r. czasopismo Podlasiak mogło poinformować: „obecnie powiat wrócił już do stanu przedwojennego”, dodając, że

w okresie od 1919 do 1928 r. odbudowano 11 świątyń, 15 budynków szkolnych ${ }^{2}$, 9 budynków użyteczności publicznej, 4672 domów mieszkalnych i 14633 zabudowań gospodarczych. Poza tym ludność powiatu z własnych funduszów w okresie 10-lecia w miastach wybudowała 72 budynków mieszkalnych murowanych oraz 778 budynków drewnianych, na wsi wybudowano 25 budynków murowanych, drewnianych zaś 3240. (,Starostwo Bialskie” 2)

Dr hab. JERZY ŻYwiCKI, prof. UMCS - Uniwersytet Marii Curie Skłodowskiej w Lublinie, Wydział Humanistyczny, Instytut Nauk o Kulturze; adres do korespondencji: Plac Marii Curie-Skłodowskiej 4, 0-031 Lublin; email: jzywicki@wp.pl; ORCID: https://orcid.org/0000-00018782-6566.

${ }^{1}$ Powiat bialski obejmował 116860 ha i dzielił się administracyjnie na piętnaście gmin wiejskich oraz trzy gminy miejskie. W 1932 r. jego obszar został powiększony o tereny siedmiu gmin ze zlikwidowanego powiatu konstantynowskiego (Dziennik Ustaw 1932, nr 6, poz. 33).

${ }^{2}$ Mimo starań akcja budowy nowych szkół przebiegała wolno i aż do wybuchu wojny nie zakończyła się sukcesem (Górny 183). 
W powiecie bialskim były tylko dwa miasta: Biała Podlaska i Terespol. Dla Białej Podlaskiej okres międzywojenny był korzystny. Miasto rozwinęło się. Działały w nim Zakłady Przemysłu Drzewnego H.B. Raabe, Zakłady Mechaniczne R. Kowieskiego, elektrownia miejska, od 1923 r. istniała Podlaska Wytwórnia Samolotów (PWS), produkująca samoloty typu szkolnego i szybowce (Demidowicz, „Biała Podlaska” 69-92). Wytwórnia w istotny sposób wpływała na rozwój przestrzenny Białej Podlaskiej, dla niej bowiem budowano nie tylko hale przemysłowe, ale także osiedla mieszkaniowe dla pracowników (,Rola sejmiku” 3$)^{3}$. W latach 20 . wybudowano według projektów architekta Władysława Kwapiszewskiego budynek dworca kolejowego, stylowo nawiązujący do renesansu. Wzniesiono go na ruinach po pierwotnym dworcu, zbudowanym w 1867 r. według projektu Alfonsa Kropiwnickiego i spalonym przez wycofujących się Rosjan w 1915 r. Nieopodal stacji kolejowej w latach 1926-1928 zbudowano wieżę ciśnień o oryginalnej bryle i żelbetowej konstrukcji. Odbudowane budynki wchodzące w skład poradziwiłłowskiego zespołu zamkowego stały się siedzibą Sejmiku, Starostwa Powiatowego, Kasy Oszczędności i Komisji Poborowej. Były w nich też mieszkania prywatne, a jedno z nich zajmował architekt Władysław Wołłodko. W 1928 r. przemianowano bialski Rynek na plac Wolności, a w połowie lat 30. uporządkowano go i nadano „nowoczesny” wygląd (Dąbrowski 126). Staraniem sejmiku powiatowego w 1928 r. zbudowano dwie siedmioklasowe szkoły powszechne. Rolę czynnika miastotwórczego stanowiło też Wojsko Polskie stacjonujące w Białej Podlaskiej. O rozwoju Białej Podlaskiej w latach Drugiej Rzeczypospolitej świadczy też sukcesywne zwiększenie się liczby mieszkańców - z około 13 tys. w $1921 \mathrm{r}$. do około 17,5 tys. w $1931 \mathrm{r}$. i ponad 20 tys. w $1939 \mathrm{r}$.

Z kolei Terespol, położony nad rzeką Bug i w odległości 7 km od Brześcia, od połowy XIX wieku funkcjonował przede wszystkim jako miasto świadczące różnego rodzaju usługi na potrzeby armii carskiej stacjonującej w twierdzy brzeskiej (Tarasiuk 6-10). Po Wielkiej Wojnie, gdy granice z Rosją przesunęły się daleko na wschód, Terespol znalazł się w centrum Polski. W opracowaniu dziejów miejscowości czytamy:

Nagłe urwanie związków z Rosją przerwało motywacyjny sens istnienia Terespola jako miasta granicznego, o znaczeniu strategicznym. Terespol opuścili już wcześniej Rosjanie, następnie co bogatsi Żydzi, którzy przenieśli swoje interesy do Brześcia, a i sami Polacy, którzy po przymusowej deportacji w głąb Rosji

\footnotetext{
${ }^{3}$ W 1929 r. PWS zatrudniała około 500 osób.
} 
w roku 1915 powrócili do Terespola, bądź nie. Przez dwadzieścia lat nic tu się nie działo. (Tarasiuk 10) ${ }^{4}$

Działo się rzeczywiście niewiele, inwestycje budowlane w Terespolu ograniczały się bowiem w latach II RP do odbudowy (po 1925 r.) dziewiętnastowiecznej bóżnicy zniszczonej podczas działań I wojny światowej, budowy siedmioklasowej szkoły powszechnej (1934-1936), 46 domów mieszkalnych, hali targowej (1937-1938), a także trzech obiektów przemysłowych: młyna motorowego Szyi Bronsztejna (1922), miejskiej rzeźni (1932-1935) i należącej do Łazarza Kalińskiego Fabryki Konserwowanych Ogórków firmy „Ogrol” (1935)

$\mathrm{Na}$ terenie powiatu bialskiego istniały początkowo tylko dwie osady miejskie $^{6}$ : Kodeń i Piszczac. Pierwsza z nich, zwana „Podlaską Częstochową", była znana zwłaszcza z sanktuarium Matki Boskiej Kodeńskiej. Kilka inwestycji budowlanych dotyczyło właśnie tego obiektu - najpierw jego przebudowy $\mathrm{w}$ drugiej połowie lat 20., następnie budowy przy nim domu dla pielgrzymów (1935), inne budowy „Ośrodka Zdrowia” (1938) i młyna motorowego Konstantego Najaka (1932), budynku zarządu gminy, rzeźni miejskiej, łaźni dla ludności żydowskiej i nowego, drewnianego mostu na rzece Bug (Demidowicz, Kodeń 25-27) ${ }^{7}$. Natomiast w Piszczacu zbudowano okazały gmach siedmioklasowej szkoły powszechnej $(1927)^{8}$, rozbudowano kościół (1931) i wyremontowano żydowską mykwę rytualną (1935). W latach 30. XX wieku rozpoczęła działalność Wytwórnia Wyrobów

\footnotetext{
${ }^{4}$ O ile w 1914 r. Terespol liczył 5544 mieszkańców, to według spisu z 1921 r. liczba mieszkańców wynosiła tylko 1919 osób.

${ }^{5}$ Terespol był znany nie tylko w kraju, ale i za granicą z uprawy oraz przetwórstwa ogórków.

${ }^{6}$ Osadami miejskimi nazywano przede wszystkim te miejscowości, którym w wyniku represji po powstaniu styczniowym odebrano prawa miejskie. Dr Józef Buzek, będący w latach 1918 1929 dyrektorem Głównego Urzędu Statystycznego w Warszawie, tak wyjaśniał znaczenie terminu „osada miejska”: „Osiedla figurujące pod tą nazwą, stanowią kategorię przejściową miedzy miastem i wsią, zostały one utworzone przez władze zaborcze rosyjskie z miejscowości, «które chociaż nazywały się miastami, jednakże z powodu nieznacznej liczby mieszkańców, małego rozwoju przemysłu i niedostateczności dochodów, w rzeczywistości nie miały znaczenia miast»" (Skorowidz miejscowości, s. nlb.).

${ }^{7}$ W 1921 r. Kodeń miał 1639 mieszkańców, a jego zabudowę tworzyły 253 domy. Miał charakter wielowyznaniowy. Obok parafii rzymskokatolickiej była w nim też parafia obrządku bizantyjsko-słowiańskiego oraz parafia prawosławna, działała gmina żydowska.

${ }^{8}$ Tygodnik Podlasiak dwukrotnie zamieszczał fotografię tej placówki, zestawiając ją z fotografią wcześniejszej szkoły (drewnianego budynku krytego strzechą). Zob. nr 12 z 1929 r. (s. 7) i nr 30-31 z 1931 r. (s. 2-3). Fotografię starej szkoły w Piszczacu, „(...) gdzie dziś istnieje piękny, piętrowy, murowany budynek szkolny”, zamieścił też Bolesław Górny w swej monografii powiatu bialskiego z 1939 r. (Górny 292).
} 
Betoniarskich A. Tarasiuka. Przez cały okres międzywojenny Piszczac był osadą rolniczo-handlową, słynącą $\mathrm{z}$ jarmarku oraz targów bydła i koni. W 1939 r. liczył mniej niż 2,5 tys. mieszkańców, a jego zabudowę, usytuowaną przy kilkunastu ulicach i częściowo wybrukowanym rynku, tworzyło 220 domów mieszkalnych (Demidowicz, Piszczac 14). Przez Piszczac przebiegała brukowana droga wojewódzka z Białej Podlaskiej do Sławatycz (Gmina Piszczac 33).

W okresie międzywojennym inwestycje dotyczące obiektów sakralnych w powiecie bialskim były nieliczne. Planowaną tuż przed wybuchem II wojny światowej budowę dużego murowanego kościoła w Huszczy ukończono dopiero w 1949 r. (Kuszneruk i Pińczuk 27, 156). Prowadzono prace przy remoncie dachu i odbudowie wież kościoła w Leśnej Podlaskiej, a także przy budowie łącznika między tą świątynią a usytuowanym obok klasztorem OO. Paulinów9 ${ }^{9}$ Przebudowywano drewnianą cerkiew w Hrudzie, co miało związek z przekazaniem jej we władanie parafii rzymskokatolickiej. Powstały dwie kaplice. Jedną, prywatną, zbudował na własny koszt i w swoim majątku Krasna (w gminie Swory) Jan Mojzych, drugą wybudowała ludność prawosławna w Kijowcu. Ponadto wzniesiono plebanie przy katolickich kościołach w Huszczy, Husince i Hrudzie, a także przy prawosławnej cerkwi w Kijowcu. Trwały intensywne prace przy wznoszeniu wiejskich szkół powszechnych. Budowano je w Bronisławowie, Ciciborze, Dąbrowicy Dużej, Dobratyczach, Dokudowie, Dubowie, Hrudzie, Husince, Huszczy, Janowie Podlaskim $^{10}$, Kijowcu, Kłodzie, Koroszczynie, Koszołach, Łobaczewie, Łomazach, Łukowcach, Międzylesiu, Marcinkowie, Mazanówce, Młyńcu, Mokranach, Matiaszówce, Olszynie, Perkowicach, Rusinie, Rossoszu, Sajówce, Terebeli, Tucznej, Woskrzenicach i Zabłociu ${ }^{11}$. W Konstantynowie i Janowie Podlaskim zbudowano domy ludowe, a w Dubowie, Kobylanach, Łomazach i Zabłociu budynki urzędów gminnych. W cytowanym już Podlasiaku powiat bialski był charakteryzowany w ten sposób: „Głównym zajęciem

\footnotetext{
${ }^{9}$ Kościół w Leśnej Podlaskiej w latach 1884-1915 był cerkwią monasteru Narodzenia Matki Bożej. Wtedy przebudowano go w duchu prawosławia. Po odzyskaniu kościoła przez paulinów prowadzono prace mające zatrzeć cerkiewny wygląd świątyni. Prace wspomniane w artykule prowadzono już po likwidacji powiatu konstantynowskiego.

${ }^{10}$ Projekt szkoły w Janowie Podlaskim powstał w 1938 r., a więc już po likwidacji powiatu konstantynowskiego.

${ }^{11} \mathrm{Z} 42$ szkół istniejących w powiecie bialskim przed I wojną światową 24 zostało spalonych, a 16 znacznie zniszczonych. W 1928 r. funkcjonowało już 78 szkół. Przeważały wśród nich niewielkie szkoły jednoklasowe (45) i dwuklasowe (24). Tylko trzy szkoły miały wówczas 7 klas. Niektóre nie dysponowały własnymi budynkami, zajmowały pomieszczenia wynajmowane w prywatnych domach. (Rola sejmiku 3).
} 
ludności jest rolnictwo. Znacznie jest też rozpowszechniona hodowla bydła i trzody chlewnej [...] Ze względu na rolniczy charakter powiatu przemysł miejscowy zajmuje się przeważnie przetworem produktów rolnych...” („Rola sejmiku" 3). Projekty budowlane $\mathrm{z}$ lat międzywojennych poświadczają trafność tej charakterystyki, budownictwo przemysłowe reprezentowały bowiem rzeźnie w Janowie Podlaskim, Łomazach i Terespolu, olejarnia w Łomazach, a przede wszystkim liczne młyny. Wśród tych ostatnich były dwa młyny wodne oraz kilkanaście młynów o napędzie motorowym: w Błotkowie, Kodniu, Kostomłotach, trzy w Łomazach (Mikołaja Wołosowicza; Fajwla Wajngartena; Jana Sakowicza i Stanisława Patkowskiego), dwa w Rossoszy (Adama Makaruka; Mieczysława Kurzawińskiego), Terespolu, Tucznej, Worgulach, Wólce Zabłockiej i Zaczopkach. Ponadto w Konstantynowie odbudowywano po wojennych zniszczeniach gorzelnię, w Łobaczewie zaś przebudowano dawną gorzelnię na obiekt mieszkalny. Nowe cegielnie założono w Chotyłowie i Kaliłowie, a tartaki w Chotyłowie i Zaciszu ${ }^{12}$. Źródła pozwalają połączyć $\mathrm{z}$ powiatem bialskim $\mathrm{z}$ okresu międzywojennego ponad czterdziestu architektów i budowniczych ${ }^{13}$. Związek większości z nich $\mathrm{z}$ tym powiatem był jednak epizodyczny. Projektowali jedną, rzadziej kilka budowli i już więcej na terenie powiatu bialskiego się nie pojawiali. Poniżej prezentujemy architektów i budowniczych powiatowych, a więc tych, dla których powiat bialski był terenem urzędowania.

Architekt powiatowy był reprezentantem państwowych władz budowlanych na powierzonym sobie terenie. Do jego obowiązków należało dopilnowywanie wszelkich spraw związanych z budownictwem. Dotyczyły one potwierdzania zgodności z rzeczywistością planów sytuacyjnych zamieszczonych na projektach architektonicznych przedstawianych do zatwierdzenia

${ }^{12} \mathrm{~W} 1931 \mathrm{r}$. w powiecie bialskim istniało: „13 młynów motorowych, 3 cegielnie polowe, w tym dwie założone przez Sejmik, jedna cegielnia z piecem Hofmana, 4 kaszarnie, 3 tartaki, 4 smolarnie, 4 betoniarnie, 2 fabryki wód gazowych oraz jedna fabryka wód owocowych" (,Monografia powiatu” 2).

${ }^{13}$ Autor artykułu przygotowuje słownik architektów i budowniczych działających w województwie lubelskim w latach 1918-1939. Informacje biograficzne dotyczące architektów i budowniczych prezentowanych $\mathrm{w}$ artykule są oparte na badaniach własnych. Oprócz osób wymienionych $\mathrm{w}$ artykule $\mathrm{w}$ powiecie bialskim zaznaczyli się jako architekci lub budowniczowie: inż. E. Borawski, F. Bychawski, inż. B. Chmielowiec, technik M. Chmielowiec, inż. arch. E. Czyż, inż. A. Dominko, inż. arch. S. Fertner, inż. G. Herbowicz, P. Ignatowski, A. Kaliczyński, arch. ogrodnik M. Kordus, inż. M. Kotowicz, inż. W. Krynkowski, inż. arch. W. Kwapiszewski, inż. arch. T. Leśniewski, technik M. Mazur, technik W. Mączyński, inż. K. Milewski, technik J. Modliński, inż. arch. A. Próchnicki, inż. B. Rymkiewicz, inż. M. Sinkiewicz, technik Z. Skulimowski, inż. A. Skwarczewski, technik F. Słotwiński, inż. B. Tomczak, budowniczy J. Wagner, inż. H. Wąsowicz, arch. H. Wdowiszewski, arch. W. Wołłodko i T. Zawadzki. 
powiatowym oraz wojewódzkim urzędom budowlanym, kontrolowanie przebiegu prowadzonych budów i sprawdzanie ich zgodności z zatwierdzonymi projektami. Do powinności tego urzędnika należało ponadto zarządzanie gmachami państwowymi znajdującymi się na terenie powiatu, przeciwdziałanie samowolom budowlanym, wstrzymywanie budów realizowanych niezgodnie z zatwierdzonymi projektami, kontrolowanie stanu technicznego istniejących już budowli i ocenianie ich pod względem ochrony przeciwpożarowej oraz bezpieczeństwa publicznego, organizowanie przetargów budowlanych przy realizacji budów finansowanych ze środków państwowych, prowadzenie statystyki ruchu budowlanego, uczestniczenie w komisjach budowlanych itd. Można uznać, że były to obowiązki niemałe, zwłaszcza wtedy, gdy teren urzędowania był rozległy, a stan sieci drogowej zły. Architektom powiatowym urzędującym w Białej Podlaskiej powierzano zaś pracę nie tylko w powiecie bialskim, ale także w sąsiadującym $\mathrm{z}$ nim powiecie konstantynowskim ${ }^{14}$.

Posadę architekta powiatowego zajmowali: inż. Zygmunt Krasiński (1920), arch. Tadeusz Prauss (1921-1922), arch. Konstanty Srokowski (1922-1925), arch. Bronisław Makowski (1925-1926), inż. arch. Adam Dzięciołowski (1926-1931) oraz inż. Eugeniusz Eberle (1932-1939). Daty podane przy nazwiskach wskazują na ciągłość obsadzenia urzędu. Tak jednak nie było, zdarzało się bowiem, że pomiędzy opuszczeniem urzędu przez jednego architekta a zajęciem go przez kolejnego mijały miesiące. Innym powodem braku obsadzenia stanowiska mógł być urlop albo choroba urzędnika. W okresach „wakatów” funkcję architekta powiatowego sprawowali zastępczo (jako „p.o. architekta powiatowego”) Ksenofont Kowalewski (styczeń 1920 i sierpień 1921), Józef Iżycki (na przełomie 1930 i 1931) oraz Michał Krzywicki (1931). Architektom powiatowym, a zwłaszcza architektom rejonowym (jak nazywano tych, którym powierzano równoczesne urzędowanie na terenie kilku powiatów) przysługiwała pomoc budowniczego powiatowego. Trudno jednak powiedzieć, czy w przypadku Białej Podlaskiej ten urząd był nieustannie obsadzony. Źródła pozwalają na łączenie z nim technika Ksenofonta Kowalewskiego (1919-1922), inż. Andrzeja Turowskiego (1932-1935), technika Aleksandra Millera (1936) oraz technika Juliana Maczugę (1939).

\footnotetext{
${ }^{14}$ Powiat konstantynowski istniał w latach 1867-1932. Jego stolicą był Janów Podlaski, a nazwa powiatu pochodziła od sąsiadującego z nią Konstantynowa. Nadano ją, by nie mylić go z powiatem, dla którego stolicą był Janów Lubelski.
} 
O Zygmuncie Krasińskim - pierwszym architekcie powiatowym w Białej Podlaskiej - wiadomo tylko tyle, że urzędował w 1920 r., potem przeniósł się do Poznania (WKB 1115).

Początki działalności architektonicznej Tadeusza Praussa były związane z Zakopanem, gdzie zapisał się jako projektant domów w stylu tyrolskim („Pomorze” i „Bezimienna”) oraz jako budowniczy schroniska przy Morskim Oku (Radwańska-Paryska i Paryski 971). Na Lubelszczyźnie pojawił się w 1921 r., by objąć urząd architekta powiatu bialskiego i konstantynowskiego. Sprawując go w 1921 r., pokierował budową drewnianego budynku garbarni Szmula Icka Wajnberga przy ul. Brzeskiej 44 w Janowie Podlaskim, a w maju 1922 r. zaprojektował wspomagany napędem motorowym drewniany wiatrak Józefa Wyczółkowskiego we wsi Bolesty (WKB 1102). W lutym i marcu 1922 r. potwierdził zgodność kilku planów sytuacyjnych w sąsiadującym z powiatem bialskim powiecie radzyńskim, w którym wówczas wakowało stanowisko architekta powiatowego. W Białej Podlaskiej przebywał do początku lata 1922 r. Przez kilkanaście następnych miesięcy pracował jako architekt powiatu biłgorajskiego, a następnie tomaszowskiego.

Konstanty Srokowski (1873-1945) był absolwentem Instytutu Inżynierów Cywilnych w Petersburgu. Do Białej Podlaskiej przybył z Brześcia nad Bugiem. Zamieszkał przy ul. Grabanowskiej 20. Równocześnie z pracą urzędniczą prowadził prywatną praktykę architektoniczną, a ponadto zarządzał tartakiem, którego był współwłaścicielem, a od czerwca 1926 r. już jedynym właścicielem. Pierwsze projekty architektoniczne wykonane przez Srokowskiego w Białej Podlaskiej są datowane na sierpień 1922 r. Zaprojektował wówczas kilka budynków i pokierował ich budową. Był to murowany młyn motorowy Piotra Korola w Kornicy, budynek rektyfikacji przy gorzelni Stanisława de Rosenwertha w Cieleśnicy, areszt przy urzędzie gminnym w Sarnakach, a także barokowy kościół pw. Trójcy Świętej w Janowie Podlaskim (WKB 1107, 1097, 1118, 1136). Ten ostatni wymagał restauracji po zniszczeniach wojennych (odbudowy zrujnowanej dzwonnicy i części nawy, reperacji dachów itd.), a ponieważ był zabytkiem, to sprawę tę traktowano priorytetowo $^{15}$. Ponadto w 1922 r. kierował budową młyna wodnego Adama Pawluczuka i Stanisława Hryciuka przy rzece Krzna w Malowej Górze i za-

${ }^{15}$ Od 1918 do 1924 r. Janów Lubelski był stolicą wskrzeszonej diecezji podlaskiej. Kościół pw. Trójcy Świętej pełnił wówczas funkcję katedry. Położenie Janowa Podlaskiego na krańcu diecezji i złe skomunikowanie drogowe z resztą jej obszaru zadecydowało o przeniesieniu w styczniu 1924 r. stolicy biskupiej do Siedlec. Remont kościoła Trójcy Świętej przeprowadzono jesienią 1924 r., a więc wtedy, gdy nie był już katedrą, a świątynią parafialną. 
projektował niewielki drewniany dom mieszkalny z gontowym dachem przy ul. Glinki w Białej Podlaskiej (WKB 303, 413). W 1923 r. wykonał projekt drewnianego kościoła w Mostowie i złożył deklarację pokierowania jego budową (WKN 1120; Ruszczyk 132, 240) ${ }^{16}$. Do realizacji zatwierdzonego już projektu jednak nie doszło, parafianie bowiem zadecydowali o budowie innej, solidniejszej, bo opracowanej w „trwałym materiale” świątyni ${ }^{17}$. Na 1923 r. są datowane jeszcze wykonane przez Srokowskiego projekty budynków urzędów gminnych z powiatu bialskiego - drewnianego w Kobylanach i murowanego w Łomazach, a także projekty kilku obiektów z powiatu konstantynowskiego - szkół powszechnych w Starych Łepkach i Janowie Podlaskim, organistówki w osadzie Sarnaki, drewnianego budynku urzędu gminnego w Pawłowie, murowanego magazynu na naftę w Platerowie, a także rozbudowy krochmalni Franciszka Wężyka w majątku Nosów (WKB 406, 408, 1132, 1135, 1117, 1100). W 1923 r. zajmował się też odbudową kilku obiektów w Białej Podlaskiej: barokowej północno-wschodniej oficyny w zespole zamkowym (w związku z przeznaczaniem jej na siedzibę Sejmiku Powiatowego), fabryki Henryka i Bernarda Raabe, a także hełmów kościoła pw. Narodzenia Najświętszej Maryi Panny (WKB 414, 320, 338). W tym samym roku pokierował jeszcze rozbudową należącej do Jadwigi Rosenwerth gorzelni „Klonownica” w Klonownicy (WKB 1098) oraz uczestniczył w wystawie architektury w Lublinie (Katalog wystawy 15). W 1924 r. zaprojektował plebanię w Kornicy, drewniany dom dla urzędu gminnego w Zabłociu, a także dwa młyny motorowe: Jana Sakowicza i Stanisława Patkowskiego w Łomazach oraz Wacława Kikłowicza w Tucznej (WKB 1123, 409, 307). W tym samym roku uczestniczył w odbudowie Podlaskiej Wytwórni Samolotów, projektując dla niej kilka obiektów (WKB 329). W 1925 r. podjął się pokierowania pracami przy wzmacnianiu kopuły w kościele pw. św. Anny w Kodniu (WKB 346) ${ }^{18}$. Równocześnie angażował się w przebudowę oficyny w bialskim zespole zamkowym. Po uwagach wojewódzkiego konserwatora zabytków, domagającego się wprowadzenia zmian w fasadzie oficyny, zrzekł się wszelkich prac przy tej inwestycji (WKB 346) ${ }^{19}$. Kilka miesięcy później na własną prośbę zwolnił się z pracy w Białej Podlaskiej i wyjechał do War-

${ }^{16}$ Grażyna Ruszczyk nie rozpoznaje twórcy projektu kościoła, nazywając go ,anonimowym autorem".

${ }^{17}$ Jej projekt opracował w 1927 r. siedlecki architekt Wacław Piasecki (WKB 1121).

${ }^{18}$ Autorem projektu był inż. Aleksander Skwarczewski z Wilna.

${ }^{19}$ Trudno powiedzieć, czego dotyczyły zalecenia konserwatora. Być może chodziło o wprowadzenie w południowej fasadzie oficyny czterokolumnowego toskańskiego portyku z balkonem. Portyk taki istnieje, a projekt Srokowskiego go nie ujmuje. 
szawy, gdzie zamieszkał przy ul. Hożej $5 / 7^{20}$. Niedługo potem zrzekł się również dozoru przy pracach budowlanych w kościele w Kodniu. Jesienią 1926 r. sprzedał nabywcom żydowskim swój tartak w Białej Podlaskiej, co Towarzystwo „Rozwój” (oddział bialsko-konstantynowski) napiętnowało wydaniem specjalnej klepsydry: „Przez popełnienie tego czynu inż. Srokowski zmarł dla społeczeństwa polskiego" (Zbiór afiszów). Z pewnością Srokowskiemu bliski był styl „swojski”, preferowany przez wielu współczesnych mu architektów, a w pierwszych latach istnienia Odrodzonej Ojczyzny zalecany przez władze rządowe. W formach niezrealizowanego kościoła w Mostowie można dopatrzeć się chęci nawiązania do osiemnastowiecznych barokowych świątyń występujących w Ziemi Sandomierskiej, takich jak np. kościół w Rogowie z 1751 r., być może znany architektowi z publikacji Wieś i miasteczko z 1916 r. (Materyaty do architektury 59, il. 158-160). W przypadku świątyni pw. Narodzenia NMP w Białej Podlaskiej praca architekta miała polegać na zastąpieniu cebulastych nakryć wież, kojarzących się z architekturą prawosławną, „rodzimymi” hełmami o barokowej stylistyce ${ }^{21}$. Natomiast $\mathrm{w}$ Janowie Podlaskim jego rola ograniczała się do doprowadzenia kościoła do stanu sprzed Wielkiej Wojny (,żadnych przeróbek remont nie przewiduje, ściśle ma być zachowany styl i charakter świątyni”) (WKB 1118). Oparte na rodzimych wzorcach miały być też budynki urzędów gminnych w Kobylanach, Łomazach i Pawłowie, dom mieszkalny dla nauczycieli przy szkole w Starych Łepkach, plebanie w Sarnakach i Kornicy. W projektach tych budowli można znaleźć wiele form uznanych za „swojskie": dachy łamane polskie lub półszczytowe, kolumnowe portyki i ganki, szczyciki z barokowymi wolutami. Niektóre z wymienionych budynków były bliższe tradycjonalistycznej architekturze proweniencji ludowej (drewniane budynki urzędów gmin w Kobylanach i Pawłowie), inne nowożytnej (murowany urząd gminy w Łomazach, hotel przy Podlaskiej Wytwórni Samolotów). W jeszcze innych niewątpliwe były inspiracje „stylem dworkowym" (murowana plebania w Kornicy), niekiedy jednak w formie mocno sprymitywizowanej, bliskiej tradycyjnemu budownictwu ludowemu (drewniane budynki urzędu gminy w Zabłociu, plebanii w Sarnakach i Zabłociu). Swoistą malowniczością odznaczał się gmach murowanej czteroklasowej szkoły powszechnej w Starych Łepkach - wydłużony, parterowy budynek

\footnotetext{
${ }^{20} \mathrm{~W}$ Warszawie w latach 30. zaprojektował kamienicę Chaima Rozena przy ul. Muranowskiej 2 oraz dwie kamienice Babińskich przy ul. Ludnej 3 i 3 a.

${ }^{21}$ Cebulaste hełmy przypominające okres, gdy świątynia pełniła funkcję cerkwi prawosławnej (1864-1915), ukazuje fotografia zamieszczona w 1929 r. w tygodniku Podlasiak (nr 12, s. 3).
} 
z dwoma bocznymi aneksami o nieco odmiennych rozwiązaniach architektonicznych. Nakrywał go wysoki dach polski z facjatami, a wejścia poprzedzały arkadowe podcienia z kolumnami. W przypadku szkoły w Tucznej rola Srokowskiego ograniczała się do dostosowania zalecanego przez Ministerstwo Wyznań Religijnych i Oświecenia Publicznego projektu wzorcowego do miejscowych warunków ${ }^{22}$, gdy zaś chodzi o szkołę w Janowie Podlaskim - do przeniesienia $\mathrm{w}$ inne miejsce drewnianego budynku zakupionego przez władze miasta, zrekonstruowania go i zaadaptowania na potrzeby szkolne. Można dostrzec, że Srokowski nawet obiektom przemysłowym starał się nadać atrakcyjną oprawę architektoniczną. Przykładem może być młyn w Kornicy - wydłużony parterowy budynek z piętrowym ryzalitem bocznym. W elewacji fasady niższej części młyna architekt zastosował kształtowane $\mathrm{w}$ tynku arkady, a ryzalit przyozdobił pilastrami i zwieńczył szczytem o falistym wykroju. Część budynków projektowanych przez Srokowskiego nie miała ciekawej formy architektonicznej, ale dobrze dopasowywała się do funkcji, do której je przeznaczono. Ta uwaga dotyczy parterowego budynku aresztu w Sarnakach oraz obiektów przemysłowych. Dla aresztu zaplanował prawie metrowej grubości mury i niewielkie okienka z podwójnymi kratami, w przypadku zaś obiektów przemysłowych zadbał o ich dobre oświetlenie i wentylację.

Bronisław Makowski (ur. 1893) był doświadczonym architektem i często zmieniał miejsca pracy. Zanim przybył do Białej Podlaskiej, był architektem $\mathrm{w}$ powiecie węgrowskim, a potem $\mathrm{w}$ tomaszowskim $\mathrm{i}$ hrubieszowskim. Jako architekt powiatu bialskiego i konstantynowskiego też pracował tylko kilka miesięcy. Dopiero po opuszczeniu Białej Podlaskiej osiadł na dłużej w Radzyniu Podlaskim, gdzie od 1926 do 1937 r. był architektem tamtejszego powiatu (a do 1931 r. także powiatu lukowskiego). Przebywając w Białej Podlaskiej, równocześnie z pracą urzędową prowadził prywatną praktykę architektoniczną. W październiku 1925 r. zaprojektował odbudowę synagogi w Łomazach, murowanej budowli nakrytej łamanym dachem polskim (WKB 356). Zaplanował ozdobienie jej fasady oraz elewacji tylnej pseudorenesansowymi attykami, a pozostałych elewacji lizenami. Trudno powiedzieć, czy te elementy zastosowano ${ }^{23}$. Przekreślenia na projekcie archi-

\footnotetext{
${ }^{22}$ Posłużono się wzorem nr 75 opublikowanym przez Ministerstwo Wyznań Religijnych i Oświecenia Publicznego w 1926 r. Autorem projektu był Aleksander Ruśkiewicz (Projekty budynków szkót powszechnych).

${ }^{23}$ Synagoga została zniszczona w czasie II wojny światowej. Brak dotyczących jej wyglądu przekazów ikonograficznych.
} 
tektonicznym mogą świadczyć o tym, że uznano je za zbędne w zatwierdzającej ten projekt Okręgowej Dyrekcji Robót Publicznych w Lublinie. W tym mniej więcej czasie Makowski kierował odbudową uszkodzonej w wyniku działań wojennych drewnianej synagogi w Terespolu, będąc zapewne także autorem projektu rekonstrukcji tej budowli (WKB 358). Być może był autorem jeszcze innych obiektów z ówczesnego terenu swego urzędowania na kilku projektach (np. opracowanej w ,stylu dworkowym” plebanii w Husince) jest jego podpis przy poświadczeniu zgodności planu sytuacyjnego z rzeczywistością, brak jednak podpisu autora projektu (WKB 350).

Adam Dzięciołowski (ur. 1886) studiował architekturę na Politechnikach we Lwowie i w Grazu, gdzie w 1918 r. otrzymał tytuł inżyniera architekta. Od 1923 r. był związany z Lubelszczyzną. Pracował jako architekt powiatowy kolejno w Lubartowie, Włodawie i Białej Podlaskiej. Co ciekawe, na ostatnim urzędzie, który zajmował od lipca 1926 r. do marca 1931 r., powierzono mu nie tylko sprawy budowlane oraz zarząd gmachami państwowymi, ale także „kulturę i sztukę" („Skład osobisty” 6). W 1928 r., angażując się w sprawy sanktuarium OO. Paulinów w Leśnej Podlaskiej, zaprojektował połączenie klasztoru z kościołem galerią wspartą na arkadzie (WKB 344). W tym samym roku wykładał w Białej Podlaskiej na kursach budowlanych przeznaczonych dla murarzy, cieśli i stolarzy („Kursy budowlane" 2-3). W 1930 r. przeprowadził remont kapitalny gmachu Seminarium Nauczycielskiego w Leśnej Podlaskiej (WKB 361), a w 1931 r. wykonał projekt rozbudowy drewnianego kościoła pw. Wniebowzięcia NMP na Woli w Białej Podlaskiej (WKB 340) ${ }^{24}$. Z pracy w Białej Podlaskiej zwolnił się na własną prośbę ${ }^{25}$. W kolejnych latach mieszkał w Toruniu.

Eugeniusz Eberle nie był architektem, a inżynierem drogowym. W latach 1932-1939 kierował Powiatowym Zarządem Drogowym i równocześnie pełnił obowiązki architekta powiatu bialskiego. Jego aktywność na polu architektury ograniczała się do potwierdzania zgodności z rzeczywistością planów sytuacyjnych zamieszczanych na projektach budowlanych. Jako „znawca techniczny” brał też udział w komisjach budowlanych, np. w 1932 r. w komisji opiniującej budowę drewnianej cerkwi w Kijowcu (WKB 355), a w 1934 r. w komisji oceniającej sprawę rozbudowy drewnianego kościoła w Hrudzie (WKB 342).

${ }^{24}$ Praca architekta dotyczyła dobudowy do tylnej ściany prezbiterium prostokątnej zakrystii. Opis nieistniejącego już kościoła w Ruszczyk 210-211.

${ }^{25}$ Być może na decyzję opuszczania zajmowanej posady wpłynęła negatywnej ocena jego pracy dokonana przez Stanisława Fertnera, architekta inspekcyjnego z lubelskiej Dyrekcji Robót Publicznych (WKB 220). 
Jak już wspomniano, w okresach ,wakatów” funkcję architekta powiatowego pełnili zastępczo jako „p.o. architekta powiatowego” Ksenofont Kowalewski, Józef Iżycki i Michał Krzywicki. Ksenofont Kowalewski (ur. 1880) z budownictwem zaznajamiał się, praktykując u warszawskich przedsiębiorców budowlanych, a także na zimowych kursach murarskich organizowanych przy Muzeum Przemysłu i Handlu w Warszawie. Od 1905 r. zatrudniał się jako podmajster $\mathrm{w}$ różnych firmach działających na terenie Galicji. Od 1915 do połowy 1919 r. urzędował jako budowniczy miejski w Nowym Targu. W lipcu 1919 r. złożył we Lwowie egzamin na dyplomowanego budowniczego, potem przeniósł się do Białej Podlaskiej, gdzie od października 1919 do marca 1922 r. był budowniczym powiatowym, a w sierpniu 1921 r. oraz w styczniu 1922 r. wypełniał zastępczo obowiązki architekta powiatu bialskiego i konstantynowskiego. Przebywając w Białej Podlaskiej, ogłaszał się na łamach Podlasiaka, że „wykonuje wszelkie plany, kosztorysy, oszacowania oraz udziela porad technicznych” („Przedsiębiorstwo budowy" 8). Znane nam projekty jego autorstwa dotyczą wyłącznie obiektów przemysłowych. W $1921 \mathrm{r}$. wykonał projekt pieców do wytapiania smoły i terpentyny w folwarku Marianka (WKB 334), a także budowy w Białej Podlaskiej fabryki narzędzi rolniczych na przedmieściu Wola (WKB 328), oraz przebudowy młyna Szmula Kreizelmana przy ul. Artyleryjskiej (WKB 294). W 1922 r. zaprojektował terpentyniarnię Wolfa Wejmana w folwarku Serwin, a także młyn i olejarnię Szyi Bronsztejna w Terespolu (WKB 306).

Józef Iżycki był architektem, absolwentem Wyższej Szkoły Przemysłowej w Krakowie. W styczniu 1930 r. został zatrudniony w Białej Podlaskiej jako rzeczoznawca budowlany, a w październiku tego samego roku jako p.o. architekta powiatowego (WKB 220, 373; „Wydział Powiatowy” 8). Wydaje się, że na tej posadzie pozostawał tylko kilka miesięcy, choć w Białej Podlaskiej przebywał dłużej (zapewne do 1936 r.). W 1931 r. kierował pracami budowlanymi przy przebudowie cerkwi w Piszczacu na kościół katolicki i najprawdopodobniej był autorem projektu tej przebudowy (WKB 349) ${ }^{26}$. Prace, których celem było najpierw zatarcie pierwotnych bizantyjsko-rosyjskich cech stylowych budowli, a następnie upodobnienia jej do kościołów katolickich, obejmowały rozbiórkę kopuły, likwidację fryzów zdobiących elewacje, budowę zakrystii i wysokiej, frontowej wieży, zamurowanie niektórych

\footnotetext{
${ }^{26}$ Murowana cerkiew w Piszczacu została zbudowana w 1907 r. W rękach prawosławnych pozostawała do 1919 r., gdy została rewindykowana na rzecz Kościoła katolickiego (Katalog zabytków sztuki 203-204).
} 
otworów, przekształcenia w wystroju wnętrza itd. Na 1931 r. datowany jest wykonany przez Iżyckiego projekt murowanej trzyklasowej szkoły powszechnej w Koroszczynie - parterowego budynku z klasycyzującym, czterokolumnowym portykiem $\mathrm{w}$ fasadzie. W $1936 \mathrm{r}$. zaprojektował murowany młyn motorowy Andrzeja i Kazimiery Bajów w Wólce Zabłockiej (WKB 309).

Michał Krzywicki (ur. 1886) dyplom inżyniera architekta otrzymał w 1925 r. na Politechnice Lwowskiej. Od 1927 do 1939 r. był związany z województwem lubelskim, w którym do 1931 r. pracował jako architekt powiatowy, a w kolejnych latach jako architekt wolnopraktykujący - autor bardzo dużej liczby projektów budowlanych. Od 1927 do 1929 r. był p.o. architekta powiatowego w Lubartowie, a od października 1929 do września 1931 r. architektem rejonu radzyńskiego (obejmującego trzy powiaty: radzyński, łukowski i lubartowski). W lipcu 1931 r. powierzono mu również powiat bialski. W tej roli jest odnotowany $\mathrm{w}$ piśmie dotyczącym przekształcenia cerkwi w Piszczacu na kościół katolicki („Ze względu na pilność mających rozpocząc się robót przy budowie kościoła, jako też niestałego urzędowania arch. pow. inż. Krzywickiego...”) (WKB 349). Nic więcej o jego „niestałym" urzędowaniu w powiecie bialskim nie wiadomo.

Z urzędem budowniczego powiatowego w Białej Podlaskiej można połączyć cztery osoby: Ksenofonta Kowalewskiego, Andrzeja Turowskiego, Aleksandra Millera oraz Juliana Maczugę. Informacje na temat Kowalewskiego zostały zamieszczone wyżej. Andrzej Turowski (ur. 1905), drugi $\mathrm{z}$ wymienionych, dobrze znał teren swego urzędowania, urodził się bowiem w Rozwadówce, a uczył w bialskim gimnazjum im. Kraszewskiego. W 1927 r. ukończył czteroletni kurs nauk na wydziale drogowo-budowlano-melioracyjnym w Średniej Technicznej Szkole Kolejowej w Brześciu nad Bugiem, otrzymując tytuł technika w zakresie drogowo-budowlano-melioracyjnym. Od jesieni 1928 do jesieni 1929 r. pracował jako technik przy budowie obiektów Osiedla Dyrekcja w Chełmie. Następnie wyjechał do Francji, by na Uniwersytecie w Caen otrzymać dyplom inżyniera cywilnego. W kwietniu 1932 r. został zatrudniony jako budowniczy powiatowy w Białej Podlaskiej. Na tym stanowisku pozostawał co najmniej do 1935 r. Znane są trzy jego prace. W 1930 r. wykonał niezrealizowany projekt drewnianego kościoła rzymskokatolickiego, który miał stanąć w dzielnicy Wola Łuski w Białej Podlaskiej (WKB 341; Ruszczyk 210-211) ${ }^{27}$. W 1935 r. zaprojektował budowę rzeźni gminnej w Łomazach (WKB 317). W 1937 r. wykonał projekt przebudowy istniejącego lokalu (dawnej siedziby kina „Mirage”) w budynku

\footnotetext{
${ }^{27}$ Grażyna Ruszczyk błędnie określa projekt kościoła jako „niesygnowany”.
} 
przy ul. Warszawskiej $1 \mathrm{w}$ Białej Podlaskiej na klub Związku Zawodowego Pracowników Lotnictwa (WKB 399). Przebudowany lokal w zależności od potrzeb miał pełnić funkcję biura, czytelni, sali gimnastycznej, sali ćwiczeń orkiestr i chórów, sali widowiskowej lub zabawowej.

Sprawy budowlane w Wydziale Powiatowym załatwia od maja 1936 r. technik budowlany Aleksander Miller, który dotychczas pełnił tę funkcję będąc kancelistą oddziału drogowego, poświęcając na ten cel 1 dzień w tygodniu. Etatu w budżecie sejmiku na utrzymanie technika budowlanego nie ma, sprawa odrębnego referatu budowlanego w Wydziale Powiatowym nie jest dotychczas uregulowana. Środków lokomocji Wydział Powiatowy na potrzeby nadzoru budowlanego nie daje, wyjazdy są ograniczone i od pewnego czasu, tam gdzie dojazd jest możliwy odbywa je własnym motocyklem, otrzymując zwrot kosztów podróży końmi... (WKB 261)

Powyższy cytat z lustracji urzędu powiatowego w Białej Podlaskiej oddaje trudną sytuację służb budowlanych w tym powiecie. O Aleksandrze Millerze wiadomo niewiele. Znane są dwa wykonane przez niego projekty: remontu drewnianego budynku mykwy rytualnej w Piszczacu (1935 r.) oraz budowy modernistycznego „Ośrodka Zdrowia” w Kodniu (1938 r.) (WKB 403).

Julian Maczuga był ostatnim budowniczym powiatu bialskiego. Legitymował się solidnym wykształceniem zawodowym (dyplomem Wyższej Szkoły Przemysłowej w Krakowie) i bogatą praktyką architektoniczno-budowlaną, jednak objęcie urzędowania w Białej Podlaskiej w 1939 r., a więc tuż przed wybuchem II wojny światowej, nie pozwoliło mu zapisać się jakąś efektywną działalnością architektoniczną czy budowlaną. Jedyne prace, z którymi można go połączyć, to usuwanie spękań w murach gimnazjum w Leśnej Podlaskiej (WKB 361) oraz wykonywanie obliczeń statycznych do projektu kościoła pw. św. Andrzeja Boboli w Huszczy (WKB 343). Autorem projektu kościoła w Huszczy był jednak nie on, a Franciszek Bychawski.

Informacji o architektach przedstawionych w tym artykule próżno szukać w leksykonach biograficznych. W opracowaniach dotyczących problematyki architektoniczno-budowlanej też się prawie nie pojawiają. I choć wiadomości tu zamieszczone również są niepełne, ograniczone do tego, co udało się odnaleźć w źródłach archiwalnych w związku z ich pracą w powiecie bialskim, to zarazem wprowadzają te postacie w obieg naukowy. To zaś co najmniej z dwóch powodów należy uznać za istotne. Po pierwsze, archi- 
tekci powiatowi byli często jedynymi przedstawicielami fachowych sił architektoniczno-budowalnych na terenie swego urzędowania. $Z$ tego względu mieli spore szanse na działalność projektową i zwykle je wykorzystywali, nierzadko osiągając przy tym interesujące efekty. Po drugie, ich nazwiska występują na projektach budowlanych przy potwierdzeniu zgodności z rzeczywistością zamieszczonych na nich planów sytuacyjnych. W przypadku projektów pozbawionych datacji wiedza o okresie urzędowania architekta powiatowego może być pomocą $\mathrm{w}$ ustaleniu czasu ich powstania.

\section{BIBLIOGRAFIA}

\section{ŹRÓDŁA}

(WKB) Archiwum Państwowe w Lublinie, Urząd Wojewódzki Lubelski 1919-1939, Wydział Komunikacyjno-Budowlany, sygn. 220, 261, 294, 303, 306, 307, 309, 317, 320, 328, 329 , $338,334,340,341,342,343,344,346,349,350,355,356,358,361,373,399,403,406$, $408,409,413,414,1097,1100,1102,1107,1115,1117,1118,1120,1121,1123,1132$, 1135, 1136, 1098,

(Zbiór afiszów) Archiwum Państwowe w Lublinie, Zbiór afiszów i druków ulotnych, sygn. 702.

Dziennik Ustaw, 1932, nr 6, poz. 33.

Górny, Bolesław. Monografia powiatu bialskiego województwa lubelskiego. Nakł. autora, 1939.

Katalog wystawy architektonicznej w Lublinie. Kwiecień 1923, oprac. Jerzy Siennicki. Drukarnia Państwowa, 1923.

„Kursy budowlane”. Podlasiak, nr 14, 1928, ss. 2-3.

Materyaty do architektury polskiej, t. 1: Wieś i miasteczko, red. Zdzisław Kalinowski, Juliusz

Kłos, Zdzisław Mączeński et al. Wydawnictwo Towarzystwa Opieki nad Zabytkami

Przeszłości. Nakładem Gebethnera i Wolffa, 1916.

„Monografia powiatu Bialskiego”. Podlasiak, nr 30-31, 1931, s. 2.

Projekty budynków szkół powszechnych, z. 2. Ministerstwo Wyznań Religijnych i Oświecenia

Publicznego. Książnica-Atlas, 1926.

„Przedsiębiorstwo budowy Budowniczy Ksenofont Kowalewski...”. Podlasiak, nr 4, 1922, s. 8.

„Rola sejmiku bialskiego”. Podlasiak, nr 12, 1929, s. 3.

Skorowidz miejscowości Rzeczypospolitej Polskiej opracowany na podstawie powszechnego spisu ludności z dn. 30 września $1921 \mathrm{r}$. i innych źródel urzędowych, t. IV: Województwo lubelskie. Główny Urząd Statystyczny, 1924.

„Skład osobisty Starostwa w Białej Podl.”. Podlasiak, nr 12, 1929, s. 6.

„Starostwo Bialskie w pierwszym dziesięcioleciu wskrzeszenia Niepodległego Państwa Polskiego (1919-1929 r.)". Podlasiak, nr 12, 1929, s. 2.

„Wydział Powiatowy Sejmiku w Białej Podlaskiej”. Podlasiak, nr 47, 1930, s. 8. 


\section{OPRACOWANIA}

Dąbrowski, Rafał. „Biała Podlaska lat 1914-1939 we wspomnieniach”. Radzyński Rocznik Humanistyczny, t. 7, 2009, ss. 134-144.

Demidowicz, Tomasz. „Biała Podlaska jako krajowy ośrodek przemysłu i sportów lotniczych w okresie międzywojennym”. Biała Podlaska. Szkice z dziejów miasta i okolic. Materiaty z sesji popularnonaukowej z okazji Dni Białej Podlaskiej 26-27 czerwca 1999 r. Miejska Biblioteka Publiczna 1999, ss. 67-92.

Demidowicz, Tomasz. Piszczac - zarys dziejów. Ośrodek Doskonalenia Nauczycieli w Białej Podlaskiej, 1999.

Demidowicz, Tomasz. Kodeń - zarys dziejów. Polskie Towarzystwo Historyczne. Zamiejscowy Wydział Wychowania Fizycznego w Białej Podlaskiej, 2006.

Gmina Piszczac. Historia i wspótczesność, red. Bogusław Korzeniowski, Andrzej Buczyła i Sławomir Hordejuk. Urząd Gminy Piszczac, 2018.

Kasprzyk, Andrzej. Biała Podlaska i okolice. Wojewódzki Ośrodek Informacji Turystycznej 1980.

Katalog zabytków sztuki w Polsce, t. VIII: Województwo lubelskie, red. Maria Kałamajska-Saeed, z. 2: Powiat Biała Podlaska, red. Katarzyna Kolendo-Korczakowa, Anna Oleńska i Marcin Zgliński, Wydawnictwa Artystyczne i Filmowe, 2006.

Kuszneruk, Józef, i Wiesław Pińczuk. Parafia rzymskokatolicka w Huszczy. Monografia parafii. Parafia Rzymskokatolicka p.w. Św. Trójcy, Warszawa-Huszcza, 1999.

Radwańska-Paryska, Zofia, i Witold Paryski. Wielka encyklopedia tatrzańska. Wydawnictwo Górskie, 1995.

Ruszczyk, Grażyna. Drewniane kościoly w Polsce 1918-1939. Tradycja i nowoczesność. Instytut Sztuki PAN, 2001.

Tarasiuk, Janusz. 500 lat Terespola. Ośrodek Wschodni - Katolickie Stowarzyszenie „Civitas Christiana" / Stowarzyszenie Rozwoju Gminy Miejskiej, 2002.

\section{ARCHITEKCI POWIATOWI W POWIECIE BIALSKIM (1918-1939). PRZYCZYNEK DO BADAŃ NAD DZIEJAMI ARCHITEKTURY WOJEWÓDZTWA LUBELSKIEGO}

\section{Streszczenie}

Architektom powiatowym urzędującym w Białej Podlaskiej w okresie międzywojennym powierzano pracę $\mathrm{w}$ dwóch powiatach: bialskim i konstantynowskim. Urząd ten sprawowali Zygmunt Krasiński (1920), Tadeusz Prauss (1921-1922), Konstanty Srokowski (1922-1925), Bronisław Makowski (1925-1926), Adam Dzięciołowski (1926-1931) oraz Eugeniusz Eberle (19321939). Daty podane przy nazwiskach sugerują ciągłość obsadzenia urzędu. Tak jednak nie było, bowiem często pomiędzy opuszczeniem go przez jednego architekta, a zajęciem go przez kolejnego mijały miesiące. Architektom powiatowym przysługiwała pomoc budowniczego powiatowego. Architekci powiatowi byli często jedynymi przedstawicielami fachowych sił architektoniczno-budowalnych na terenie swego urzędowania. $Z$ tego powodu mieli spore szanse na działalność projektową i zwykle je wykorzystywali. Ważne jest też to, że ich nazwiska występują na projektach budowlanych przy potwierdzeniu zgodności z rzeczywistością zamieszczonych na nich planów sytuacyjnych. W przypadku projektów pozbawionych datacji wiedza o okresie urzędowania architekta może być pomocą w ustaleniu czasu ich powstania.

Słowa kluczowe: architekci powiatowi; budowniczowie powiatowi; powiat bialski; powiat konstantynowski; okres międzywojenny. 


\title{
THE POWIAT ARCHITECTS \\ OF THE BIAŁA PODLASKA POWIAT (1918-1939): \\ A CONTRIBUTION TO THE RESEARCH ON THE HISTORY \\ OF THE ARCHITECTURE OF THE LUBLIN VOIVODSHIP
}

\begin{abstract}
Su m mary
During the interwar period of 1918-1939, powiat (county) architects in Biała Podlaska were also entrusted with tasks in the neighbouring powiat of Konstantynów. The position of powiat architect was filled by Zygmunt Krasiński (1920), Tadeusz Prauss (1921-1922), Konstanty Srokowski (1922-1925), Bronisław Makowski (1925-1926), Adam Dzięciołowski (1926-1931) and Eugeniusz Eberle (1932-1939). The dates suggest a continuity of office; however, this was not always the case, as it sometimes happened that months passed between the departure of one architect and the assumption of the office by the next. The powiat architect was assisted in turn by a powiat chief builder. These architects were often the only representatives of professional architectural and construction expertise in their area of authority. For this reason, they had a good chance of being involved in design projects and usually took such opportunities when they arose. It was also important that their names appeared on construction projects when confirming their compliance with the actual site plans attached to them. In the case of undated building projects, information about the term of office of the powiat architect can help determine the date their design was developed.
\end{abstract}

Keywords: powiat architects; powiat chief builders; Biała Podlaska powiat; Konstantynów powiat; interwar period. 


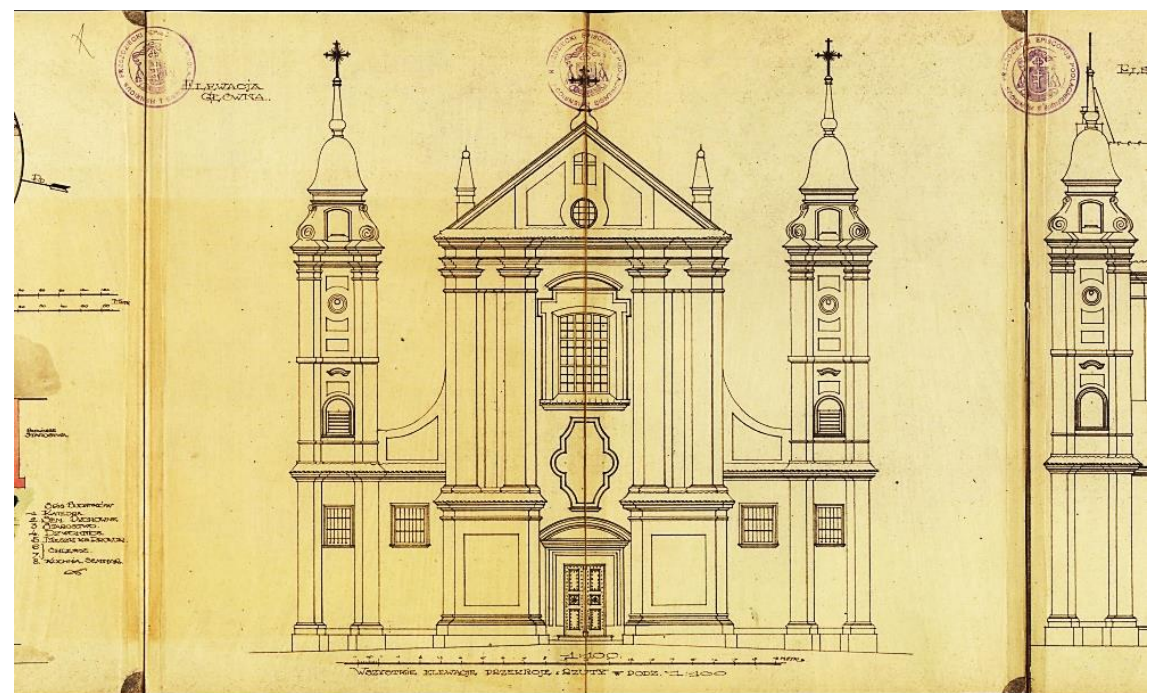

1. K. Srokowski, projekt katedry w Janowie Podlaskim, 1922.

Archiwum Państwowe w Lublinie, Urząd Wojewódzki Lubelski 1919-1939,

Wydział Komunikacyjno-Budowlany, sygn. 1118.

Fot. Pracownia Reprograficzna Archiwum Państwowego w Lublinie

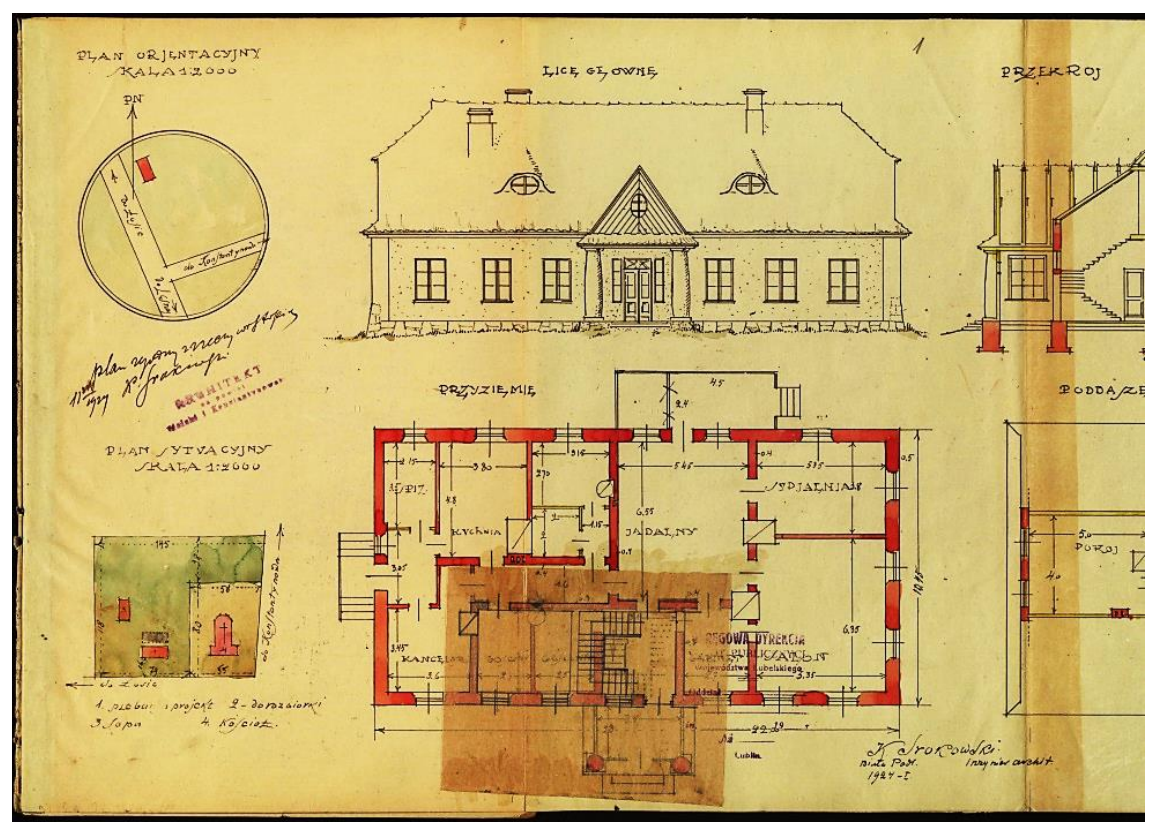

2. K. Srokowski, projekt plebanii w Kornicy, 1924. Archiwum Państwowe w Lublinie, Urząd Wojewódzki Lubelski 1919-1939, Wydział Komunikacyjno-Budowlany, sygn. 1123. Fot. Pracownia Reprograficzna Archiwum Państwowego w Lublinie 


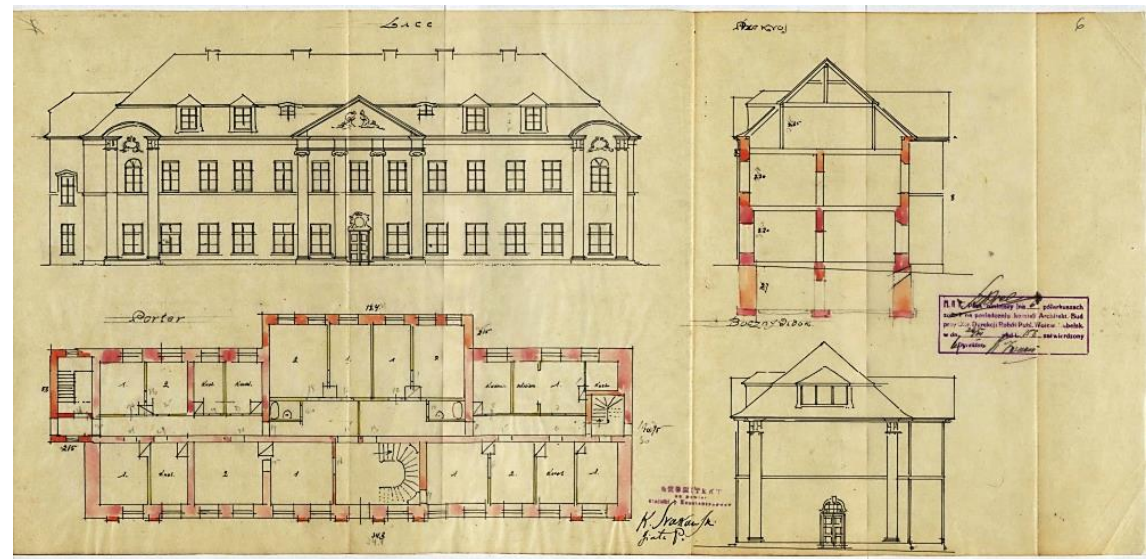

3. K. Srokowski, projekt przebudowy oficyny przy zamku w Białej Podlaskiej, 1923. Archiwum Państwowe w Lublinie, Urząd Wojewódzki Lubelski 1919-1939, Wydział Komunikacyjno-Budowlany, sygn. 414.

Fot. Pracownia Reprograficzna Archiwum Państwowego w Lublinie

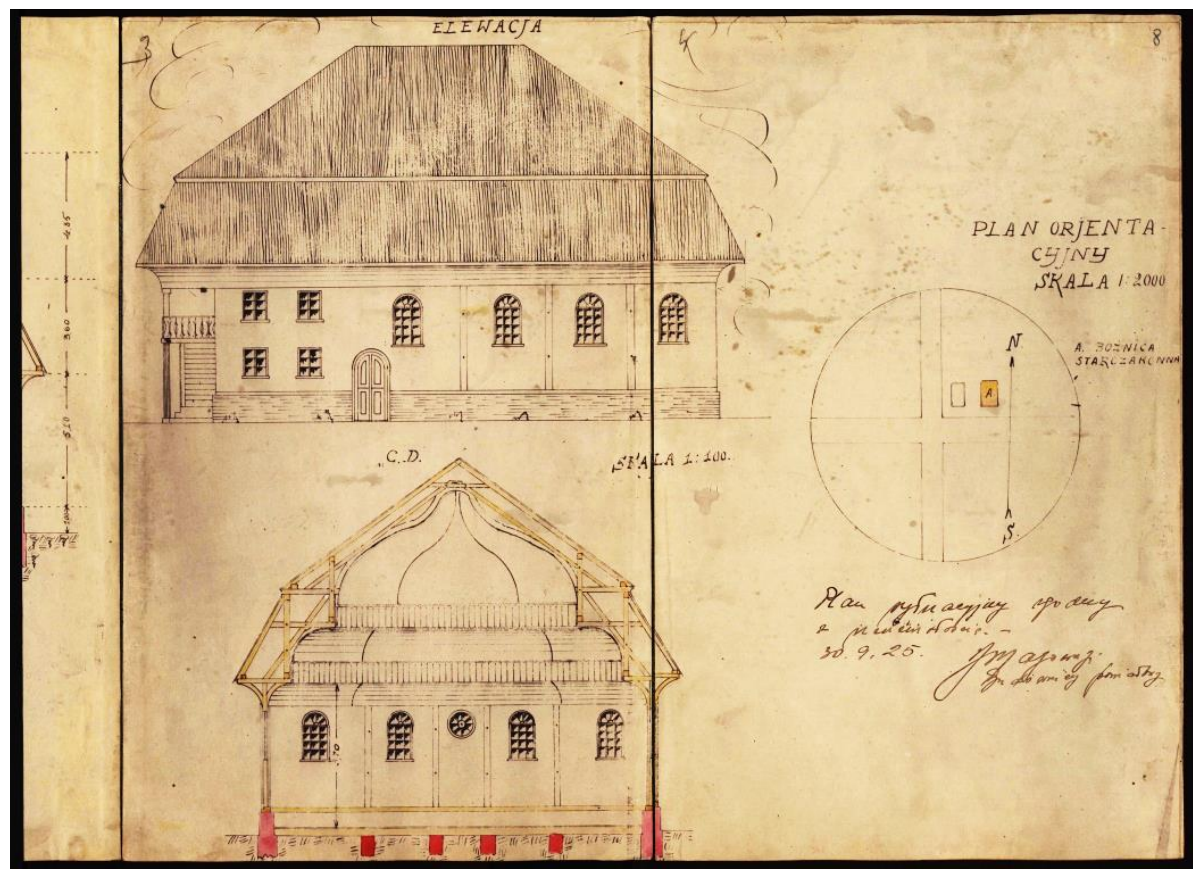

4. Projekt bożnicy w Terespolu, 1923.

Archiwum Państwowe w Lublinie, Urząd Wojewódzki Lubelski 1919-1939,

Wydział Komunikacyjno-Budowlany, sygn. 358.

Fot. Pracownia Reprograficzna Archiwum Państwowego w Lublinie 


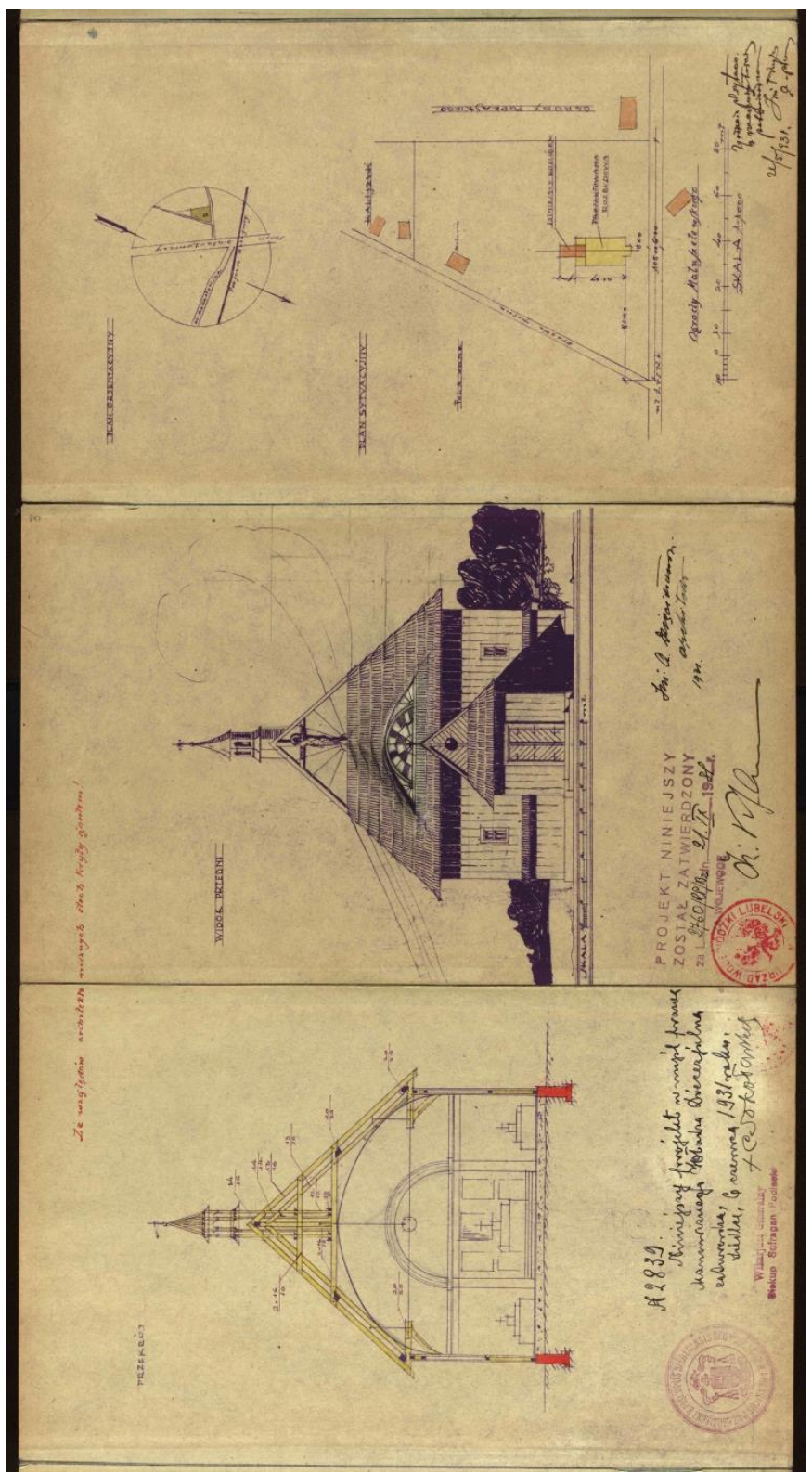

5. A. Dzięciołowski, projekt rozbudowy istniejącego kościoła na „Woli” w Białej Podlaskiej, 1931.

Archiwum Państwowe w Lublinie, Urząd Wojewódzki Lubelski 1919-1939, Wydział Komunikacyjno-Budowlany, sygn. 340.

Fot. Pracownia Reprograficzna Archiwum Państwowego w Lublinie 